sciendo Порівняльна професійна педагогіка 9(4)/2019 Comparative Professional Pedagogy 9(4)/2019

DOI: $10.2478 /$ rpp-2019-0034

$\mathrm{PhD}$ in Pedagogy, Associate Professor, NATALIYA BHINDER Bohdan Khmelnytskyi National Academy of the State Border Guard Service of Ukraine Address: 46 Shevchenko St., Khmelnytskyi, 29000, Ukraine E-mail: berestetskanat@ukr.net

\title{
THE SYSTEM OF PROFESSIONAL TRAINING OF BORDER GUARDS AT HIGHER EDUCATIONAL ESTABLISHMENTS IN THE REPUBLIC OF INDIA
}

\begin{abstract}
The article concerns the description of the system of professional training of border guards at the higher educational establishments in the Republic of India and distinguishing its structural components. To achieve the purpose of the research we used two groups of methods: quantitative and qualitative. Quantitative methods include analysis of statistical data, structural method, method of additional analysis of data, study of specific object, and juxtaposition. Qualitative methods concern analysis of normative documents, literature review, observation, method of scientific description of information, and comparative method. According to theoretical findings system approach enables to consider professional training as an integrated system with regard to its subsystems. Also, it is regarded as a specific strategy or set of techniques used to solve the particular problem - training of future expert. In our case, the pedagogical objective is to train highly-qualified border guard. The author described the system of professional training of border guards at the higher military educational establishments in the Republic of India in details. We have found that the system of professional training of border guards at the higher military educational establishments in the Republic of India consists of nine structural components. They are the following: legislative, management, institutional, methodological, targeted, organizational, content, technological, and result. Each component has its own peculiarities and coverage. The combination of all the structural components enables the system of professional training be effective and achieve the objectives. The uniqueness of the study of the system of professional training of border guards at the higher military educational establishments in the Republic of India concerns the fact that its structural components were not described before in one work. And the explanation of interrelation of structural components is very important for professional training itself and contributes to enhancing the efficiency of the educational process.

Keywords: system of professional training, border guards, system approach, higher military educational establishments, structural component.

\section{АНОТАЦІЯ}

У статті здійснено опис системи професійної підготовки приордонників у вищих військових навчальних закладах Республіки Індія, а також виокремлено ї̈ структурні компоненти. Для досягнення мети дослідження використано дві групи методів: кількісні та якісні. Кількісні методи включають аналіз статистичних даних, структурний метод, метод додаткового аналізу даних, вивчення окремого об'єкта та метод зіставлення. Якісні методи включають аналіз нормативних документів,
\end{abstract}


sciendo Порівняльна професійна педагогіка 9(4)/2019 Comparative Professional Pedagogy 9(4)/2019

огляд літератури, спостереження, метод наукового опису інформації, а також порівняльний метод. Відповідно до результатів дослідження системний підхід дає можливість розглядати професійну підготовку як інтегровану систему по відношеню до ї̈ підсистем. Також, системний підхід стосується певної стратегї̈ чи набору методів, які використовують для вивчення окремої проблеми - підготовки майбутнього фахівия, у нашому випадку - підготовка високопрофесійного фахівия охорони кордону. Автор детально описує систему професійної підготовки прикордонників у вищих військових навчальних закладах Республіки Індія. Також у ході дослідження з'ясовно, щз система професійної підготовки прикордонників у вищих військових навчальних закладах Республіки Індія складається з певних структурних компонентів (нормативний, управлінський, змістовий та інші). Кожен з компонентів має свой особливості та межі. Взаємодія иих структурних компонентів забезпечує ефективність системи професійної підготовки та досягнення педагогічної мети. Новизна дослідження системи професійної підготовки прикордонників у вищих військових навчальних закладах Республіки Індія полягає у тому, щзо раніше ії структурні компоненти не були виокремлені та описані у самостійному дослідженні. Обгрунтовано взаємозв'язок структурних компонентів, які є дуже важливими для системи професійної підготовки та сприяє підвищенню ефективності освітнього проиесу.

Ключові слова: система професійної підготовки, прикордонники, системний підхід, вищі військові навчальні заклади, структурний компонент, Індія.

\section{INTRODUCTION}

Socio-economic and political development of the country is impossible without the security of the state, including border security. At the same time, the efficient strategy of border security requires the efficient system of professional training of border guards. The problem of improvement of the system of professional training of border guards at the higher educational establishments in the Republic of India complicates due to the diverse threats at the border, changing conditions and dynamic technological changes under the globalization processes.

Considering this fact, there is a need for detailed study of the system of professional training of border guards at the higher educational establishments in the Republic of India in order to ensure its efficient work and positive interrelation of its structural components.

\section{THE AIM OF THE STUDY}

The aim of the research is to study the system of professional training of border guard at the higher military educational establishments in the Republic of India, to describe its structural components and to show their interrelation.

\section{THEORETICAL FRAMEWORK AND RESEARCH METHODS}

The system approach to professional training of future specialists is a topic of many researches. K. Murthy, M. Ranganath, P. Checkland, and P. Davies outlined the theoretical principles of system approach to professional training. K. Sampath, A. Panneerselvam, S. Santhanam, and M. Giridhar analyzed the system approach at the Indian higher educational establishments and proved its efficiency under the modern conditions of Indian society. And the same time B. Pama, G. Sen, and P. Mallick studied the system of professional training of future officers, including future officers of border agencies. However, we have to say that there are no works devoted to the detailed analysis 
of the structural components of the system of professional training of border guard at the higher military educational establishments in the Republic of India.

While investigating the problem of the system of professional training of border guards in the Republic of India we used two groups of methods: quantitative and qualitative. Quantitative methods (analysis of statistical data, structural method, method of additional analysis of data, study of specific object, and juxtaposition) are oriented towards the search for differences in order to find out discrepancies and attribute them to different factors of the problem. Qualitative methods (analysis of normative documents, literature review, observation, method of scientific description of information, and comparative method) are used to compare a large number of objects and to draw logical conclusions within the comparative education study.

\section{RESULTS}

The study of professional training of border guards in the Republic of India is based on the system approach. According to K. Murthy and M. Ranganath (1979) system approach concerns the analysis of the process of professional training as an integrated system with regard to its subsystems, and P. Checkland (1981) affirms that system approach is a specific strategy or set of methods used to solve the particular problem training of future expert. It includes the usage of scientific methods for observation, determination, identification of problem, and to solve it while analyzing the interrelation between its different components taking into consideration their characteristics and qualities.

The process of professional training of border guards at the higher military educational establishments in the Republic of India has to be analyzed as a generalized holistic system where input components are cadets, objectives of training, and recourses of the educational process. At the same time, the system embraces output component - a highly-qualified professional of border guard agency (Murthy and Ranganath, 1979; Davies, 2000; Sampath et al., 2008). That is why system approach to professional training is a rational and effective method to solve and important pedagogical problem - a professional training to perform his/her service duties in a more efficient manner.

M. Giridhar (1994) characterizes the system approach to professional training on the basis of the following conditions: determination of boundaries of the system and its environment; outlining of system objectives; conformity with tasks of educational objectives; management of the system according to the well-designed plan. K. Sampath et al. (2008) define system approach to professional training as a rational and effective method to educate future professionals.

System approach is focused on the analysis, planning and implementation of the process of training but not its separate parts. Simultaneously, the system approach maintains the holistic view upon the problem of professional training of border guard officers and considers it as a mandatory stage of continuous educational process ensuring the integrity of its components. We agree with M. Giridhar (1994) that stresses that to achieve the efficiency of the system of professional training, all its components must interact and interdepend. Also, all participants should be aware of the peculiarities of the interrelation of these components to maximize the system.

According to the studies (Pama, 2008; Sen, 2013; Mallick, 2017) devoted to the problems of system of professional training of border guards in the higher educational establishments in the Republic of India from the point of view of its integrity, we can claim that it includes a number of structural components. They are the following: legislative, management, institutional, methodological, targeted, organizational, content, technological, and result. We would like to analyze them in details. 
sciendo Порівняльна професійна педагогіка 9(4)/2019 Comparative Professional Pedagogy 9(4)/2019

Legislative component. Current system of professional training in the Republic of India is regulated and controlled with a number of legislative and normative acts in the sphere of educational and security sector developed by the Department of Higher Education of the Ministry of Human Resources Development, National Assessment and Accreditation Council, National Board of Accreditation. Also, higher military educational establishments belong to state sector are supervised by official organs regarding the field of knowledge (All India Council for Technical Education, Distance Education Bureau, Bar Council of India, National Council for Teacher Education). Higher military education is also regulated by the Ministry of Home Affairs and Ministry of Defense. Central organs of executive power carry out the state policy in the sphere of military education at the federal level and provide control over the quality of educational and scientific activities of state institutions.

Management component. Considering the social significance of military education and the need to adhere for the standards in the process of professional training of servicemen, including border guards, and following the requirements for the acquisition of professional competence, in the republic of India there are some organs supervising the quality of educational process at the higher military educational establishments. Thus, the Ministry of Defense includes the Army Education Corps within the General Staff Department headed by Director General of Military Training. The Army Education Corps develops and approves the training programs of servicemen, controls joint trainings and special training establishments like the Counter-Insurgency and Jungle Warfare School in Vairengte, Mizoram. The Army Training Command (ARTRAC) is one of the structural elements of the Army Education Corps. It was founded in 1991 to assist the improvement of the system of professional training of servicemen in the Republic of India.

The Army Education Corps, along with the Department of Border Management of the Republic of India, control the agency-specific educational establishment. The department of modernization of police organs is responsible for technical maintenance of the educational process to improve the system of professional training of future border guards (Vaid, 1998). Also, the Army Education Corps and the Department of Border Management of the Republic of India are responsible for appointment of officers from active units to higher military educational establishments to conduct special courses.

Institutional component. Higher military education in the Republic of India contributes to improvement of scientific and professional training, retraining and advanced training of personnel for military formations and law-enforcement organs. Higher military educational establishments in the Republic of India are the following: university, academy, institute, college, officers' training school and junior officers' training school. Higher military educational establishments train professionals for the security sector at the bachelor and master level. Also, they provide postgraduate training in the field related to border security.

Considering that in the Republic of India there are five border agencies (Border Security Force, Indo-Tibetan Border Force Police, Sashastra Seema Bal, Assam Rifles, and Coast Guard), all institutions can be divided into five groups. Thus, the Border Security Force personnel are trained at the agency-specific officers' training schools and the Border Security Force Academy. The personnel of Indo-Tibetan Border Force Police are trained at the agency officers' training schools and Indo-Tibetan Border Force Police Academy that was founded as High Altitude Defense And Survival Academy. The officers of Sashastra Seema Bal study at the agency-specific officers' training schools and Sashastra Seema Bal Academy. There is no separate institution for training officers for Assam Rifles, and the agency personnel are trained and retrained at the Indraprastha Defense Academy. The 
sciendo Порівняльна професійна педагогіка 9(4)/2019 Comparative Professional Pedagogy 9(4)/2019

Personnel for the Coast Guard study at the Coast Guard Academy. The officers of all agency undertake postgraduate training at the National Defense University.

Methodological component. Currently in the theory of professional training of border guards in the Republic of India, we trace the following concepts: revivalism, rationalism, humanism, integration, positivism, patriotism, cosmopolitism, eclectism, idealism, realism, and pragmatism (Sharma, 2003; Banerjee, 2003). While investigating the methodological basis of professional training of border guards, we distinguished the following approaches competencebased, personality-based, andragogical, and ethno-axiological (Salas, 2003; Dobhal, n/a; Singh, 2011). Besides we outlined the principles of professional training of border guards in the Republic of India that are pedagogical laws characterizing general strategy of solving pedagogical problems and means of enhancing the efficiency of the training itself. The main principles of professional training of border guards are divided into two groups exterior (principle of quality, principle of adherence, principle of integrity, principle of unity of interests, principle of cadre selection, Gandhi principle, and state support principle) and interior (general pedagogical, psychological-pedagogical, organizational-pedagogical, and specific principles) (Aggarwal, 1986; Bhatia and Purohit, 1983; Banerjee, 2003).

Targeted component. Higher military education has to be systemic, scientific, holistic, reformistic, combined; it must evolve in accordance with the requirements of time and tasks facing border agencies. Higher military educational establishments provide future border guard officers with knowledge and skills necessary for professional activities. Also, the objective of agency-specific institutions is to form the model of professional behavior in future expert of border security sector and to build his/her tactical and administrative ability (Dobhal, n/a).

Raj (2010) admits that due to the existence of varied and intensive operative tasks facing Indian border guards and rapid technological changes in the system of border security, the system of professional training of border guards is constantly changing and the higher military educational establishments must adapt their training programs to ensure educational efficiency and correlate the process of training with real professional activities.

Organizational component. Analysis of pedagogical literature (Pama, 2008; Sen, 2013; Mallick, 2017; Dobhal, n/a; Vaid, 1998; Raj, 2004) and the study of normative documents show that the system of training of professional training of border guards is constantly changing and the higher military educational establishments in the Republic of India is realized at three levels: bachelor's, master's and postgraduate. At the same time, the system includes two main stages: higher military education of junior officers and higher military education for senior officers.

Higher education for junior officers means professional training of junior border guard officers at the higher military educational establishments. It concerns general military, operational, administrative, logistics, and special training of cadets who joined the first year of studying at the institution or decided to undertake retraining program. Higher military education for junior officers takes place at the universities, academies, colleges, officers' training schools, and junior officers' training centers. To provide system higher education for junior officers, the Ministry of Defense and Ministry of Home Affairs developed the Guidelines for the implementation of higher military education for junior officers. In accordance with the document, the professional training of junior officers includes theoretical and practical training.

Higher military education for senior officers concerns the training of officers of middle and higher ranks and is oriented towards the development of their professional 
sciendo Порівняльна професійна педагогіка 9(4)/2019 Comparative Professional Pedagogy 9(4)/2019

knowledge and special skills provided by normative documents and regulations of border agencies. Also, higher military education for senior officers deals with the carrying out of scientific researches within the master's and postgraduate programs. This stage of professional training includes physical training ( $25 \%$ of study time), military and special training of agency-specific profile (50\% of study time), practical training $(10 \%)$ and psychological training $(10 \%)$. Higher military education for senior officers takes place at the universities, academies, institutes and officers' training schools.

Content component. The content of the professional training of border guards in the Republic of India is divided into two blocks: general military and agency specific (Pama, 2008; Raj, 2004; Bhinder, 2017). It is explained by the fact that there are five agencies in the country, and each of them has its own duties and operates in the designated border sectors.

General military subjects include Drill training, Marksmanship, Physical training, Military tactics, Driving, Border management, Counter-terrorism operations, Counterinsurgency operations, Joint operations, Service regulations, Military law, English, Hindi, History of India, Military campaigns of India.

Considering agency-specific subjects, they are the following. Cadets at the Border Security Academy study Use of means of fortification, Use of heavy weapons, Horse and camel riding, Survival in swamps, and Solo patrolling. The training program at the Indo-Tibetan Border Force Police Academy includes Hand-to-hand fighting (judo), Horse riding, and Foreign language (Chinese Mandarin or Tibetan language). The future border guard officers for Assam Rifles study Jungle war, Horse riding, Survival in mountains and jungles, and Use of a hot-air balloon. Sashastra Seema Bal Academy training program includes Reconnaissance, Rescue operations, Escort of civil populations through mountains, Work with local communities and indigenous people, Smuggling prevention, and Detecting of counterfeit notes. Agency-specific training at the Coast Guard Academy includes Poaching prevention, Smuggling prevention, and Protection of the inclusive marine economic zone.

Such an approach allows enhancing the efficiency of professional activities at the border significantly.

Technological component. Indian didactics is realized through traditional and innovative teaching methods. Traditional methods include the following: lectures, seminars, practical lessons, discussion, demonstration. At the same time, to enhance the efficiency of the learning process, innovative methods are widely implemented.

According to Looney (2009) implementation of innovations in education is a condition of development of the system and ensuring the high standards of future professionals' training.

The implementation of a number of innovations within the system of professional training of border guards at the higher educational establishments in the Republic of India is provided under a number of reasons. First of all, it is the peculiarities of border security strategy and an extension of tasks facing border guard officers. Also, innovations are substantiated by the lack of highly-qualified academic and teaching staff; the need for operational solving of problems concerning the process of training of a large amounts of personnel for border agencies; the necessity to form professional competence and individual psychological characteristics of future border guard officers, the need for decrease of psychological and physical load upon the cadets, and the requirement to decrease financials expenses without affecting the quality of professional training.

The innovative methods include cascade training, capsule training, microteaching, cross-training, horizontal training, the usage of simulation technologies including simulators for 
improvement of technical skills and computer-based war game, active teaching methods to work in small groups (focus group, teamwork, achievement groups, round table, panel discussion, game, just a minute, work with video, study section, think-pair-share, buzz group), active teaching methods to work in large groups (question-answer, horizontal training, massive learning environment, interactive lecture, pause procedure, clicker, conceptTest, assessment work, minute papers, team-pair-solo, wall walk, question of the day, hidden lecture, war game) and active teaching methods for independent work (mosaic learning, study section, project work, flipped classroom, horizontal learning, and self-guided learning). Separate group of innovations comprise psychological methods oriented towards the formation of individual psychological characteristics of future border guard officers (Bhinder, 2018; Chauhan, 2013; Duta, 1999; Venkata Reddy, 2002; Chakraborty, 2010).

Result component. It is oriented towards the control and evaluation of the result of the process of professional training of border guards in the Republic of India. On the basis of results, the appropriate conclusions are made and necessary changes are implemented to improve the system of professional training of border guards at the higher military educational establishments. In the Republic of India, the principle of independent evaluation is applied that means educational process involves the third party to assess the level of readiness of cadets. Usually it is a separate organ within the system of professional training at the agency-specific higher military educational establishment that is responsible for the monitoring of cadets' achievements during the period of studying and assessment upon the completion of the studies (Center for Civil Society, 2016).

\section{CONCLUSIONS}

The studies showed that system of professional training of border guards at the higher military educational establishments in the Republic of India includes a number of structural components. They are the following: legislative, management, institutional, methodological, targeted, organizational, content, technological and result.

Legislative component concerns the legislative and normative documents regulating the educational process. Management component deals with the structure of supervisory bodies responsible for the training programs and introduction of modernization elements. Institutional component shows that the system of professional training of border guards at the higher military educational establishments is divided into three levels: bachelor, master and postgraduate. Within the system, there are agency-specific establishments training border guards for certain agency. Methodological component concerns concepts, approaches and principles; targeted deals with objectives, content component touches upon the development of general military and agency specific content of professional training. Technological component concerns the training methods used to implement professional training and make it more effective. Result component is oriented towards the outcome of the professional training highly-qualified border guard officer that is ready to perform professional duties.

Further, we are planning to distinguish relevant elements within the system of professional training of border guards in the Republic of India and study the possibilities for their creative implementation within the system of training of cadets in Ukrainian higher military educational establishments.

\section{REFERENCES}

1. Aggarwal, J. C. (1986). Theory and Principles of Education: Philosophical and Sociological Bases of Education. New Delhi: Vikas Publishing House.

2. Banerjee, A. (2003). Philosophy and Principles of Education. Kolkata: B B Kundu. 
sciendo Порівняльна професійна педагогіка 9(4)/2019 Comparative Professional Pedagogy 9(4)/2019

3. Bhatia, K. K., \& Purohit, T. (1983). Principles and Practice of Education. New Delhi: Kalyani Publishers.

4. Bhinder, N. V. (2017). Content analysis of professional training of border guards in the Republic of India. Studies in Comparative Education, 3-4 (33-34), 18-26.

5. Bhinder, N. (2018). Analiz innovatsiinykh tekhnolohii u protsesi profesiinoi pidhotovky prykordonnykiv u Respublitsi Indiia. Naukovi zapysky Ternopilskoho natsionalnoho universytetu imeni Volodymyra Hnatiuka. Series: Pedagogy, 2, 132-139.

6. Center for Civil Society. (2016). New Education Policy: Principles, Priorities \& Practices. Retrieved from: https://ccs.in/nep.

7. Chakraborty, C. (2010). The Hindu ascetic as fitness instructor: Reviving faith in yoga. In S. R. Chakraborty, S. Chakrabarti, and K. Chatterjee (Eds), The Politics of Sport in South Asia (pp. 24 - 38). Abington-Oxon: Routledge.

8. Chauhan, S. (2013). Enhancing Training Through Use of Simulations. CLAW Journal, Summer Issue, 188-208.

9. Checkland, P. (1981). Systems thinking, systems practice. New York: John Wiley and Sons Ltd.

10. Davies, P. (2000). The relevance of systematic reviews to educational policy and practice. Oxford Review of Education, 26 (3\&4), 365-378.

11. Dobhal, P. (n/a). Education in Indian Army: An Analysis. Retrieved from http://pggc46.ac.in/images/EDUCATION\%20IN\%20INDIAN\%20ARMY.pdf.

12. Dutta, D. (1999). Simulation in Military Training: Recent Developments. Defense Science Journal, 49 (3), 275-285.

13. Giridhar, M. (1994). Systems approach to management education in India a study with special reference to university business schools. Ananthapuramu: Sri Krishnadevaraya University.

14. Looney, J. W. (2009). Assessment and Innovation in Education. OECD Education Working Papers, 24, 62.

15. Mallick, P. K. (2017). Professional Military Education: An Indian Experience. New Delhi: Vivekananda International Foundation.

16. Murthy, K. K., \& Ranganath, M. V. (1979). Systems approach to Technological education. Proceedings of the IFAC Conference. Cairo, Arab Republic of Egypt: International Federation of Automatic Control.

17. Pama, B. (2008). Paradigm Shift in Training in the Army. New Delhi: KW Publishers Pvt. Ltd.

18. Raj, R. (2010). Global Encyclopedia of Military Education and Training. New Delhi: Global Vision Publishing House.

19. Salas, E. (2003). Training Evaluation in the Military: Misconceptions, Opportunities, and Challenges. Military Psychology, 15 (1), 3-16.

20. Sampath, K. et al. (2008). Introduction to Educational Technology. New Delhi: Sterling Publishers Private Limited.

21. Sen, G. (2013). Professional Military Education in India: The emerging Scenario. Indian Higher Education: Perception, Policies and Practices, 1 (1), 44-60.

22. Sharma, G. R. (2003). Trends in Contemporary Indian Philosophy of Education: A Critical Evaluation. New Delhi: Atlantic Publishers and Distributors. Issue, $72-78$

23. Singh, N. (2011). Unconventional: Training for Being. Combat Journal, April

24. Vaid A. (1998). A Quest for Excellence: Training the Indian Army. Shimla: ARTAC Press.

25. Venkata Reddy, K. (2002). Changing Attitudes to Education in India. New Delhi: Atlantic Publishers and Distributors. 